\title{
INCIDENCE AND DETERMINANTS OF LOWER LIMB SALVAGE FOLLOWING ARTERIAL LIGATION IN INFECTED PSEUDOANEURYSM IN INTRAVENOUS DRUG ABUSERS
}

\author{
Abdelrahman Magdy Ahmad, Mostafa Soliman Abd El Bary, Amr Nabil Kamel
}

Department of Vascular Surgery, Ain Shams Faculty of Medicine, Ain Shams University, Egypt

Corresponding author:

AbdelrahmanMagdy

E-mail:

drabdelrahmanmagdy2012@med.asu .edu.eg

Mobile number: 01009955723

Received: $23 / 9 / 2020$

Accepted: $14 / 10 / 2020$

Online ISSN: 2735-3540

\begin{abstract}
:
Background: Infected femoral artery pseudoaneurysms (IFAPs) in Intravenous drug abusers (IVDAs) are very common nowadays with increasing incidence and controversial management strategy with little data about correlation between IFAPs criteria and limb outcome.
\end{abstract}

Aim of the work: to estimate incidenceand determinants of limb salvage post arterial ligation in patients with infected pseudoaneurysms.

Patients and Methods: Prospective cohortwith18 months follow up of 40 IVDA patients presented with groin pseudoaneurysms to estimate incidence and determinants of Lower Limb salvage following Arterial Ligation.

Results:Duration of Intravenous (IV) addiction ranged from half a year to 30 years and affected groin use ranged from half a year to 10 years and duration of symptoms ranged from 1 to 6 weeks. Symptoms ranged between swelling in 13 cases (32.5\%), pulsating mass in 12 cases (30\%) and hemorrhage in 15 cases (37.5\%). DVT found in 31 cases (77.5\%). Incidence of limb salvage post arterial ligation is $75 \%(N 30)$, threatened limbs found in $25 \%$ of cases (N 10). Amputation required in 15\%(N 6) and bypass in 12.5\%(N 5) bypass followed by amputation in one patient. Primary patency of all constructed bypasses is 6 months for $80 \%$ (N 4) and 3 months for $20 \%$ (N 1).Viral markers showed 33 patients were $H C V$ +ve $(82.5 \%), 8$ patients $H B V+v e(20 \%)$, 9 patients $H I V+v e(22.5 \%)$. There was statistically significant difference between both groups as regard duration of affected groin use, duration of symptoms, nature of presenting symptom, Pre and immediate post-operative ABI and percent of reduction between both and Level of ligation are determinants of limb salvage

Conclusion: Ligation and debridement with selective revascularization strategy is a safe option in IFAPs management.Incidence of limb salvage following arterial ligation is $75 \%$. Duration of affected groin use, duration of symptoms, nature of presenting symptom, Pre and immediate post-operative ABI and percent of reduction between both and Level of ligation are determinants of limb salvage.

Keywords: drug abusers, infected femoral pseudoaneurysms, limb salvage, ligation of groin vessels, IVDAs: intra venous drug abusers.

\section{INTRODUCTION:}

Infected femoral pseudoaneurysms are a common presentation in intravenous drug abusers (IVDA) with little consensus as to the optimum management of these patients. Whilst emergency revascularisation options are available, excision and ligation of the 
femoral artery remains the most common operative intervention but risks leaving the patient with critical ischaemia or intermittent claudication. ${ }^{(1)}$

Pseudoaneurysm in IVDA is mostly mycotic that occurs as a consequence of infection after direct arterial injury. They represent a fulminant infectious process, which, if untreated, may result in systemic sepsis, rupture and exsanguination. Historically, mycotic pseudoaneurysms were classified pathophysiologically based on the mode of arterial infection: direct arterial infection from an area of suppuration (primary), septic embolus with arterial occlusion (secondary) - frequently in the context of infective bacterial endocarditis, and finally, as a consequence of adherence of viable pathogens in the arterial wall in patients with systemic sepsis. ${ }^{(2)}$

Some surgeons advocate artery ligation and local debridement alone, with acceptableresults. However, there is no level I evidence to support these procedures and the quality of results is questionable as they are based on a small clinical series with poor follow-up. Moreover, up to now, there has been no report to investigate which characteristic infected femoral artery pseudoaneurysm can be treated by artery ligation and local debridement alone without any fear of ischemic complications. ${ }^{(3)}$

\section{PATIENTS AND METHODS:}

This prospective cohort study was conducted by simple sampling of 40 IVDA patients $\mathrm{N}=40$. Age ranged between 24 and 56 year old admitted with infected femoral pseudoaneurysm and managed by ligation and debridementas the sole management for all patients.

Patients were enrolled from Jan 2018 to Jan 2019 at Ain Shams University Hospitals. Patients' informed written consent and Local Ethical Committee approval have been obtained before patients' allocation.Patients presented with lost limb at time of presentation were excluded from the study.

Pre-Operative: All patients diagnosed on clinical basis of ruptured femoral pseudoaneurysm, pulsating mass or non pulsating mass with duplex or CT angiogram confirming pseudoaneurysm if patient's condition permits. Emergency resuscitative measures and compressive dressings were applied immediately to patients presenting with ruptured pseudoaneurysms with external bleeding. Demographic data and relevant history were recorded (Age, Sex, duration of IV addiction, duration of affected groin use and duration of symptoms). Careful clinical examination conducted and recorded (presenting symptom, leg status, preoperative Ankle brachial Index ABI). Complete blood count, renal functions, PT, PTT, INR and viral markers (HCV, HBV, HIV) were performed for all cases.Imaging in the form of arterial duplex done in 13 cases presented with nonpulsating masses and duplex confirmed presence of pseudoaneurysm. CT angiogram done in 4 cases and confirmed presence of pseudoaneurysm. Imaging not done in cases presented with frank hemorrhage.

Operative procedure: All cases were managed by retroperitoneal exposure of iliac vessels to ensure proximal control and to assess extension of infection. Distal Superficial Femoral Artery (SFA) control was done to decrease bleeding from pseudoaneurysm exposure as much as we can. Then cases were managed by exploration of pseudoaneurysm and ligation of affected vessel and local debridement of infected tissues with ligation as low as safe for iliac vessels and as high as safe for femoral vessels to maintain collateral circulation. Level of proximal ligation was recorded, iliac exposure and SFA exposure wounds were closed primarily but pseudoaneurysm wounds were left for healing by secondary intention in all cases. Presence or absence of DVT was recorded either from duplex scan or assessment of 
vein during exposure. Immediate post operative $\mathrm{ABI}$ were recorded at the end of procedure.

Post-operative: follow up was done immediately after ligation and hourly close monitoring for 6 hours then every 6 hours for 48 hours to assess leg perfusion by capillary refilling, Doppler signals, coldness, motor power and patient's general condition " blood pressure, conscious level, inotropic support, ABG and creatine kinase level " to decide between no further intervention, above knee amputation or bypass construction if the patient requires further intervention. Decision was taken on individual basis.Patients were allocated after ligation into 2 groups: group1 of nonthreatened limbs post ligation and Group 2 with threatened limbs post ligation "required secondary intervention in the form of bypass or amputation through study time". In patients with threatened limbs but were not amenable for revascularization due to extensive tissue loss following debridement, lack of safe bypass construction planes or bad general condition, above knee amputation was performed. Criteria of a non-salvageable limb included tender and tense calf muscles, total loss of motor power, profound fixed cyanosis, fixed mottling of the limb, sever acidosis and hyperkalemia related to ischemic leg.In patients with threatened limbs and the general condition permits and in presence of safe planes, construction of ilio-femoral bypass was done through obturator foramen if safe medial planes "done in one case only" or through lateral subcutaneous approach "done in 4 cases "all bypasses were constructed by synthetic ringed $8 \mathrm{~mm}$ graft.

Further follow up done via outpatient clinic visits and phone calls at 6,12 and 18 months to assess leg viability via capillary refilling and ABI, wound status and photographs were taken after consent, construction of bypass if signs of critical ischemia develops, assessment of constructed bypasses and assessment of amputation wounds.

Chosen determinants:Preoperative ABI, Level of ligation, duration of intravenous drug abuse, Extent of infection (above or below inguinal ligament), Presence or absence of DVT, duration of symptoms and duration of affected groin use.

Statistical analysis: The collected data was revised, coded, tabulated and introduced to a PC using Statistical package for Social Science (SPSS 25). Data was presented and suitable analysis was done according to the type of data obtained for each parameter.

\section{RESULTS:}

Demographic data showed that age (ranged from 24 and 56) and sex (38 males 95\%, 2 female 5\%). (table 1)

Table (1): Demographic data of patients:

\begin{tabular}{|c|c|c|c|c|c|}
\hline \multicolumn{2}{|c|}{} & Mean / N & SD / \% & Median (IQR) & Range \\
\hline \multirow{2}{*2}{ Age } & 38.1 & 8.1 & $36.5(33-42)$ & $(24-56)$ \\
\hline \multirow{2}{*}{ Sex } & Male & 38 & $95.0 \%$ & & \\
\cline { 2 - 7 } & Female & 2 & $5.0 \%$ & & \\
\hline
\end{tabular}

Addiction history showed Duration of Intravenous (IV) addiction ranged from half a year to 30 years with a mean of 6.9 years and affected groin use ranged from half a year to 10 years with a mean of 3.4 years and duration of symptoms ranged from 1 to 6 weeks with a mean of 3.2 weeks. 
Table (2):Addiction history:

\begin{tabular}{|l|c|c|c|c|}
\hline & Mean & SD & Median (IQR) & Range \\
\hline duration of IV addiction (ys) & 6.9 & 6.8 & $5(2-10)$ & $(0.5-30)$ \\
\hline Duration of affected groin use (ys) & 3.4 & 2.4 & $3.25(1-5)$ & $(0.5-10)$ \\
\hline duration of symptoms ( weeks ) & 3.2 & 1.4 & $3(2-4)$ & $(1-6)$ \\
\hline
\end{tabular}

Viral markers showed that 33 patients HCV +ve (82.5\%), 7 patients HBV +ve (17.5\%), 9 patients HIV +ve (22.5\%). (table 3 )

Table (3): Viral markers:

\begin{tabular}{|c|c|c|c|c|c|}
\hline \multicolumn{2}{|c|}{} & Mean / N & SD $/ \%$ & Median (IQR) & Range \\
\hline \multirow{3}{*}{ HCV } & No & 7 & $17.5 \%$ & & \\
\cline { 2 - 6 } & Yes & 33 & $82.5 \%$ & & \\
\hline \multirow{3}{*}{ HBV } & No & 33 & $82.5 \%$ & & \\
\cline { 2 - 6 } & Yes & 7 & $17.5 \%$ & & \\
\hline \multirow{2}{*}{ HIV } & No & 31 & $77.5 \%$ & & \\
\cline { 2 - 7 } & Yes & 9 & $22.5 \%$ & & \\
\hline
\end{tabular}

Right groin was affected in 20 cases $50 \%$ and left was affected on the other 20, $50 \%$. Symptoms ranged between swelling in 13 cases $32.5 \%$, pulsating mass in 12 cases $30 \%$ and hemorrhage in 15 cases 37.5 $\%$. Infection extension above the inguinal Table (4): Clinical examination:

\begin{tabular}{|c|c|c|c|}
\hline & & $\mathrm{N}$ & $\%$ \\
\hline \multirow[t]{2}{*}{ Groin } & $\mathrm{Rt}$ & 20 & $50.0 \%$ \\
\hline & $\mathrm{Lt}$ & 20 & $50.0 \%$ \\
\hline \multirow[t]{2}{*}{ Swelling } & No & 27 & $67.5 \%$ \\
\hline & Yes & 13 & $32.5 \%$ \\
\hline \multirow[t]{2}{*}{ pulsating mass } & No & 28 & $70.0 \%$ \\
\hline & Yes & 12 & $30.0 \%$ \\
\hline \multirow[t]{2}{*}{ haemorrhage } & No & 25 & $62.5 \%$ \\
\hline & Yes & 15 & $37.5 \%$ \\
\hline
\end{tabular}

Intra operative findings showed Infection extension above the inguinal ligament found in 23 cases $57 \%$ and confined to below inguinal ligament area in 17 cases $42.5 \%$. DVT found in 31 cases 77.5 $\%$ and no DVT in 9 cases $22.5 \%$, Level of ligament found in 23 cases $57 \%$ and confined to below inguinal ligament area in 17 cases $42.5 \%$. Total Leucocytic count ranged from 5.7 to 51.3. DVT found in 31 cases $77.5 \%$ and no DVT in 9 cases $22.5 \%$. (table 4)

ligation was at femoral level in 18 patients $45 \%$, external iliac in 19 patients $47.5 \%$ and common iliac in 3 patients $7.5 \%$. Loss of follow up of total 6 patients at different intervals of follow up time. (table 5). 
Table (5): Operative and follow up Data:

\begin{tabular}{|c|c|c|c|}
\hline & Yes & 2 & $5.0 \%$ \\
\hline \multirow{3}{*}{ Infection Level } & Above inguinal ligament & 20 & $50.0 \%$ \\
\cline { 2 - 4 } & Below inguinal ligament & 20 & $50.0 \%$ \\
\hline \multirow{2}{*}{ DVT } & No & 9 & $22.5 \%$ \\
\cline { 2 - 4 } & Yes & 31 & $77.5 \%$ \\
\hline \multirow{2}{*}{ level of ligation } & Femoral & 18 & $45.0 \%$ \\
\cline { 2 - 4 } & External iliac & 19 & $47.5 \%$ \\
\cline { 2 - 4 } & Common Iliac & 3 & $7.5 \%$ \\
\hline \multirow{2}{*}{ Bypass } & No & 35 & $87.5 \%$ \\
\cline { 2 - 4 } & Yes & 6 & $12.5 \%$ \\
\hline Amputation & No & 10 & $85.0 \%$ \\
\cline { 2 - 4 } & Yes & 30 & $15.0 \%$ \\
\hline \multirow{2}{*}{ Salvage } & No & & $75.0 \%$ \\
\cline { 2 - 4 } & Yes & 5 & \\
\cline { 2 - 4 } & & & $34.0 \%$ \\
\hline
\end{tabular}

Table (6): Bypass Group data:

\begin{tabular}{|c|c|c|c|}
\hline \multicolumn{2}{|c|}{} & $\mathrm{N}$ & $\%$ \\
\hline \multirow{2}{*}{ Bypass } & No & 35 & $87.5 \%$ \\
\cline { 2 - 4 } & Yes & 5 & $12.5 \%$ \\
\hline \multirow{2}{*}{$\begin{array}{c}\text { time of bypass in days from } \\
\text { ligation }\end{array}$} & .0 & 1 & $20.0 \%$ \\
\cline { 2 - 4 } & 1.0 & 1 & $20.0 \%$ \\
\cline { 2 - 4 } & 2.0 & 2 & $40.0 \%$ \\
\cline { 2 - 4 } & 60.0 & 1 & $20.0 \%$ \\
\hline Primary Patency of bypass (Ms) & 3.0 & 1 & $20.0 \%$ \\
\cline { 2 - 4 } & 6.0 & 4 & $80.0 \%$ \\
\hline
\end{tabular}

Limb salvage by ligation only achieved in 30 cases $75 \%$. Threatened limbs found in 10 cases $25 \%$ (amputation done in 6 cases and bypass constructed in 5 cases) with bypass followed by amputation in one case. Bypass constructed in one patient immediately POD0 as the patient was presented with acutely ischemic but viable limb and at $1^{\text {st }}$ POD for second patient, $2^{\text {nd }}$ POD for 2 cases and $60^{\text {th }}$ POD for the last patient of bypass group (N 5). Primary patency of all constructed bypasses found to be 6 months for $80 \%(\mathrm{~N} 4)$ and 3 months for $20 \%$ (N 1) with secondary intervention required in $60 \%$ patients.

\section{Comparison analysis of groups:}

Comparison analysis of both groups showed no statistically significant difference in demographic data or laboratory data between both groups as regard limb salvage. 
Table 7: Relation between salvage and demographic data

\begin{tabular}{|c|c|c|c|c|c|c|}
\hline & \multicolumn{2}{|c|}{ Salvage } & \multirow{2}{*}{\multicolumn{3}{|c|}{ Test of significance }} \\
\hline & & \multirow{2}{*}{$\begin{array}{c}\text { No } \\
\text { Mean } \pm \text { SD } \\
\mathrm{N}(\%)\end{array}$} & \multirow{2}{*}{$\begin{array}{c}\text { Yes } \\
\text { Mean } \pm \text { SD } \\
\mathrm{N}(\%) \\
\end{array}$} & & & \\
\hline & & & & Value & p-Value & Sig. \\
\hline \multicolumn{2}{|c|}{ Age } & $39.3 \pm 9.29$ & $37.67 \pm 7.74$ & $t=0.550$ & $0.586^{(\mathbf{T})}$ & NS \\
\hline \multirow[t]{2}{*}{ Sex } & Male & $8(21.05 \%)$ & $30(78.95 \%)$ & & \multirow[t]{2}{*}{$0.058^{(\mathbf{F})}$} & \multirow[t]{2}{*}{ NS } \\
\hline & Female & $2(100 \%)$ & $0(0 \%)$ & & & \\
\hline
\end{tabular}

(T) Student t-test of significance. ( $\mathrm{t}=$ student $\mathrm{t}$-test value)

(F) Monte-Carlo Fisher's Exact test of significance.

Comparison analysis of addiction data showed statistically significant difference between 2 groups in duration of affected groin use and duration of symptoms.

Table 8: Relation between salvage and addiction history

\begin{tabular}{|c|c|c|c|c|c|}
\hline \multirow{2}{*}{} & \multicolumn{2}{|c|}{ Salvage } & \multicolumn{3}{c|}{ Mann-Whitney test } \\
\cline { 2 - 5 } & No & Yes & \multicolumn{2}{|c|}{ P-Value } & Sig. \\
\cline { 2 - 5 } & Median (IQR) & Median (IQR) & $U$ & 0.059 & NS \\
\hline $\begin{array}{c}\text { duration of IV } \\
\text { addiction (ys) }\end{array}$ & $2(1.5-5)$ & $6(3-10)$ & 90 & 0.017 & $\mathrm{~S}$ \\
\hline $\begin{array}{c}\text { Duration of affected } \\
\text { groin use (ys) }\end{array}$ & $1(0.5-3)$ & $4(1.5-6)$ & 74.5 & $<0.001$ & $\mathrm{~S}$ \\
\hline $\begin{array}{c}\text { duration of symptoms } \\
\text { (weeks ) }\end{array}$ & $1(1-2)$ & $4(3-4)$ & 25 & \\
\hline
\end{tabular}

Comparison analysis of signs showed statistically significant difference between 2 groups in presenting symptom.

Table 9: Relation between salvage and signs.

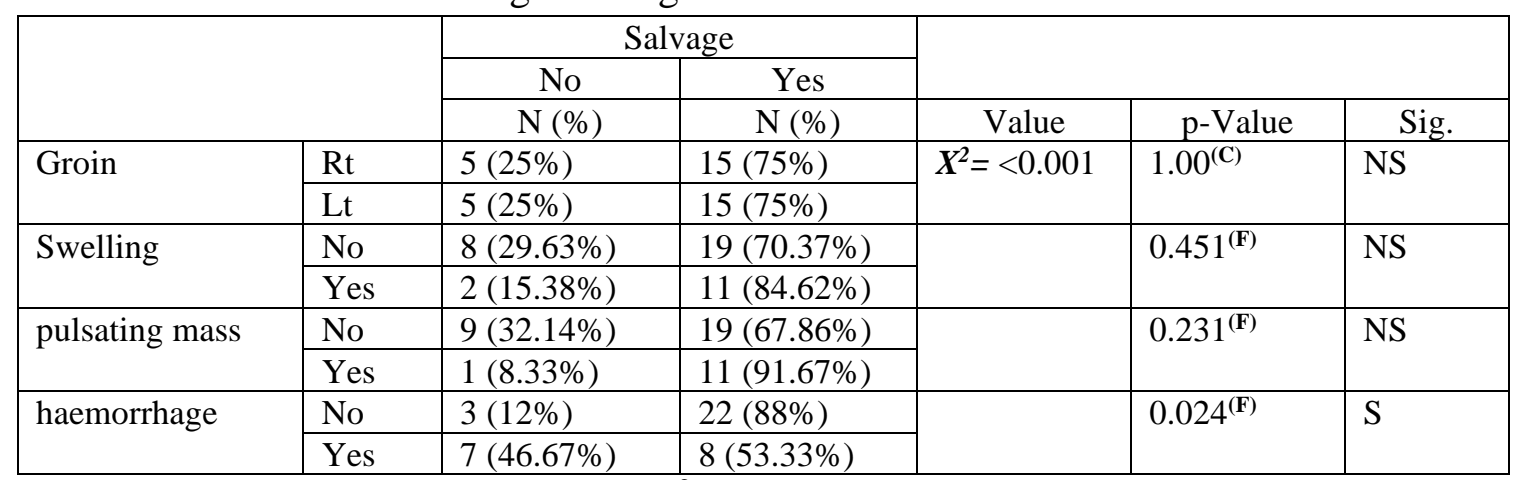

(C) Chi-Square test of significance. $\left(\mathrm{X}^{2}=\right.$ Chi-square test value $)$

(F) Monte-Carlo Fisher's Exact test of significance.

Level of ligation was related statistically to immediate postoperative ABI and percent of reduction. 
Table 10: Relation between level of ligation and ABI.

\begin{tabular}{|c|c|c|c|c|c|c|}
\hline & \multicolumn{3}{|c|}{ level of ligation } & \multirow{2}{*}{\multicolumn{3}{|c|}{ One Way ANOVA }} \\
\hline & Femoral & External iliac & Common Iliac & & & \\
\hline & Mean \pm SD & Mean \pm SD & Mean \pm SD & $f$ & p-Value & Sig. \\
\hline $\begin{array}{c}\text { Preoperative } \\
\text { ABI }\end{array}$ & $0.86 \pm 0.15$ & $0.88 \pm 0.12$ & $1 \pm 0$ & 1.380 & 0.265 & NS \\
\hline Immediate post & $0.52 \pm 0.19$ & $0.29 \pm 0.18$ & $0 \pm 0$ & 14.315 & $<0.001 *$ & $\mathrm{~S}$ \\
\hline $\begin{array}{l}\text { Percent of } \\
\text { reduction }\end{array}$ & $39.7 \% \pm 19.8 \%$ & $64.7 \% \pm 25.7 \%$ & $100 \% \pm 0 \%$ & 12.051 & $<0.001 *$ & $\mathrm{~S}$ \\
\hline
\end{tabular}

Comparison analysis of signs showed statistically significant difference between 2 groups in pre-operative $\mathrm{ABI}$ and immediate post-operative $\mathrm{ABI}$ and percent of reduction between both.

Table 11: Relation between salvage and ABI follow up

\begin{tabular}{|c|c|c|c|c|c|}
\hline \multirow{2}{*}{} & \multicolumn{2}{|c|}{ Salvage } & \multicolumn{3}{c|}{ Student t-test } \\
\cline { 2 - 5 } & No & Yes & \multicolumn{2}{|c|}{ Sig. } \\
\cline { 2 - 5 } & Mean \pm SD & Mean \pm SD & $t$ & p-Value & S \\
\hline preoperative ABI & $0.98 \pm 0.07$ & $0.85 \pm 0.14$ & 3.700 & 0.001 & $\mathrm{~S}$ \\
\hline immediate post & $0.07 \pm 0.07$ & $0.47 \pm 0.18$ & -9.731 & $<0.001$ & $\mathrm{~S}$ \\
\hline Percent of reduction & $93.1 \% \pm 7.3 \%$ & $44.7 \% \pm 21.4 \%$ & 10.542 & $<0.001$ & \\
\hline
\end{tabular}

Comparison analysis of signs showed statistically significant difference between 2 groups in Level of ligation and no significant relation as regard presence or absence of DVT and infection level.

Table 12: Relation between salvage and other determinants

\begin{tabular}{|c|c|c|c|c|c|c|}
\hline & \multicolumn{2}{|c|}{ Salvage } & \multirow{2}{*}{\multicolumn{3}{|c|}{ Test of significance }} \\
\hline & & \multirow{2}{*}{$\begin{array}{c}\text { No } \\
\text { N (\%) }\end{array}$} & \multirow{2}{*}{$\begin{array}{c}\text { Yes } \\
\mathbf{N}(\%)\end{array}$} & & & \\
\hline & & & & ue $^{\text {Val }}$ & $\begin{array}{c}\text { p- } \\
\text { Value }\end{array}$ & ig. \\
\hline \multirow{2}{*}{$\begin{array}{c}\text { Infection Level } \\
\text { Above inguinal lig } 1 \\
\text { below inguinal } \\
\text { ligament } 2\end{array}$} & $\begin{array}{l}\text { Above inguinal } \\
\text { ligament }\end{array}$ & $3(15 \%)$ & $17(85 \%)$ & \multirow[t]{2}{*}{$\begin{array}{c}X^{2}= \\
2.133\end{array}$} & \multirow[t]{2}{*}{$0.144^{(\mathbf{C})}$} & \multirow[t]{2}{*}{ NS } \\
\hline & $\begin{array}{l}\text { Below inguinal } \\
\text { ligament }\end{array}$ & $7(35 \%)$ & $13(65 \%)$ & & & \\
\hline \multirow[t]{3}{*}{ DVT } & No & $2(22.22 \%)$ & $7(77.78 \%)$ & & \multirow[t]{3}{*}{$1.00^{(\mathbf{F})}$} & \multirow[t]{3}{*}{ NS } \\
\hline & Yes & $8(25.81 \%)$ & $23(74.19 \%)$ & & & \\
\hline & Yes & $5(100 \%)$ & $0(0 \%)$ & & & \\
\hline \multirow[t]{3}{*}{ level of ligation } & Femoral & $1(5.56 \%)$ & $17(94.44 \%)$ & & \multirow[t]{3}{*}{$0.002^{(\mathbf{F})}$} & \multirow[t]{3}{*}{$\mathrm{S}$} \\
\hline & External iliac & $6(31.58 \%)$ & $13(68.42 \%)$ & & & \\
\hline & Common Iliac & $3(100 \%)$ & $0(0 \%)$ & & & \\
\hline
\end{tabular}

\section{DISCUSSION:}

Management of pseudoaneurysm patients is a challenging aspect with no guidelines or level 1 evidence about the optimum management. In literature, management plans ranged between: table $13,{ }^{(4)}$
Ligation only without revascularization, Ligation with immediate revascularization in all cases, Ligation selective revascularizetion "delayed" and the least popular endovascular management by covered stents. 
Table 13:Management options from previous Papers

\begin{tabular}{|c|c|c|c|c|c|}
\hline & Patients & Procedure & $\begin{array}{l}\text { Amputation } \\
\text { rate }\end{array}$ & $\begin{array}{c}\text { Graft } \\
\text { infection }\end{array}$ & Remarks \\
\hline Rammell et al(1) & 4 & Ligation only & $25 \%$ & - & \\
\hline Naqi et al (9) & 17 & Ligation only & $23 \%$ & - & \\
\hline Arora et al (8) & 6 & Ligation only & $0 \%$ & - & $\begin{array}{l}\text { +ve Pedal Flow in } \\
\text { all patients after } \\
\text { ligation }\end{array}$ \\
\hline Klonaris et al (10) & 14 & $\begin{array}{l}\text { Immediate } \\
\text { revasculrisation }\end{array}$ & $7.1 \%$ & $7.1 \%$ & $\begin{array}{l}\text { Autogenous conduits } \\
86 \%\end{array}$ \\
\hline Lashkarizadeh et al(11) & 21 & $\begin{array}{l}\text { Selective } \\
\text { (14 LE, } 5 \text { R, } 2 \\
\text { B) }\end{array}$ & $5 \%$ & - & $\begin{array}{l}\text { Prospective wait and } \\
\text { see }\end{array}$ \\
\hline Majeed et al (12) & 13 & $\begin{array}{l}\text { Selective } \\
\text { (9 LE, } 4 \text { B) }\end{array}$ & $7.6 \%$ & $75 \%$ & $\begin{array}{l}\text { Retrospective/ no } \\
\text { criteria mentioned }\end{array}$ \\
\hline Pradhan et al (13) & 10 & $\begin{array}{c}\text { Selective } \\
\text { (3 LE, } 7 \text { B) }\end{array}$ & $0 \%$ & $57 \%$ & $\begin{array}{l}\text { Retrospective/ no } \\
\text { criteria mentioned }\end{array}$ \\
\hline Tan et al (14) & 13 & $\begin{array}{l}\text { Selective } \\
\text { (6 LE, } 7 \text { B) }\end{array}$ & $0 \%$ & $14.2 \%$ & $\begin{array}{l}\text { Retrospective/ no } \\
\text { criteria mentioned }\end{array}$ \\
\hline Mousavi et al (6)* & 134 & Ligation only & $0 \%$ & - & $\begin{array}{l}\text { Retrospective/ no } \\
\text { criteria mentioned }\end{array}$ \\
\hline Antoniou et al (15)* & 2 & Endovascular & $0 \%$ & - & $\begin{array}{l}1 \text { patient lost and } \\
\text { one thorombosed }\end{array}$ \\
\hline
\end{tabular}

LE: ligation excision, R: repair, B: bypass $*$ Study added to the original table

Our study design is unique as it is a prospective cohort study with follow up time of 18 months and most studies of this population are designed as retrospective cohort with small sample size and short term follow up. Loss of follow up is a major problem in this population reflected by these studies.

Ligation without revascularization is a simple option with good results and is advocated by many surgeons. ${ }^{(1,3,6,8,9)}$ This reduces the risk and morbidity of graft infection and or hemorrhage due to septic rupture of anastomosis which could be fatal. Most of the concerns about this management option stem from a report by DeBakey and Simeone in 1946 in which ligation of SFA and CFA resulted in amputation rates of $54 \%$ to $86 \%$ respectively ${ }^{(5)}$. However, these data were among military wounds and we don't believe that this population can be compared to IVDAs population as they don't have the same factors that stimulate arteriogenesis in IVDAs as recurrent arterial injuries, micro emboli, infection, nicotine and opioids.

The biggest support of this management option comes from Mousavi et al series ${ }^{(6)}$ who reported 134 patients managed by ligation and only 2 patients required minimal amputations in the form of forefoot and one toe amputations. On the other hand, some series showed that ligation only strategy resulted in amputation of $25 \%$ of cases. ${ }^{(1)}$

In a large retrospective study over 461 patients, Georgiadis et al reported that immediate (routine) revascularization strategy using either in situ or extraanatomic bypass has also been associated with high complication rates. Even when it occurs through non-infected tissue planes, the risk of graft infection (early, $21.1 \%$; late, $32.4 \%$ ) is of great concern, and the possibility of sepsis (together with anastomotic dehiscence (14\%) and even amputation) is high (early, 9.8\%; late, $11.3 \%) .{ }^{(7)} \mathrm{We}$ believe that immediate bypass construction is not favorable as it increases the risk of graft infection and or failure 
while delayed bypass construction carries better outcome. In our bypass cases only 1 patient required immediate revascularization as he was presented with acute ischemia but viable limb and IFAP and subclinical infection was found in this graft as it was found thrombosed and removed after 6 months, after removal patient did not require any further intervention and all wounds are healed and he has only non-limiting claudication pain.

Taking the balance between these management options, we advocated the selective revascularization strategy after ligation and excision of infected tissues. In most papers there were no predictors or determinants for bypass construction or amputation in ligated patients.

There is no strong evidence about the best modality for assessment of leg viability intraoperatively after ligation as clinical assessment of motor or sensory power can't be done, capillary refilling and Doppler flow signals may also be affected by vasospasm and patient's hemodynamic instability. Tell now, Doppler flow seems to be the most reliable factor in assessment of leg vascularity intraoperatively. Based on this, we calculated and recorded the immediate Post-operative ABI and percent of ABI reduction.

We found a statistically significant reduction of $\mathrm{ABI}$ in relation to level of ligation as shown in table 10 .

We allocated patients $\mathrm{N}=40$ into 2 groups: Patients were group1 of nonthreatened limbs post ligation $\mathrm{N}=30$. Group 2 with threatened limbs post ligation $\mathrm{N}=10$ "required secondary intervention in the form of bypass $\mathrm{N}=5$ or amputation through study time $\mathrm{N}=6$ ". Bypass followed by graft removal then amputation occurred in same patient.

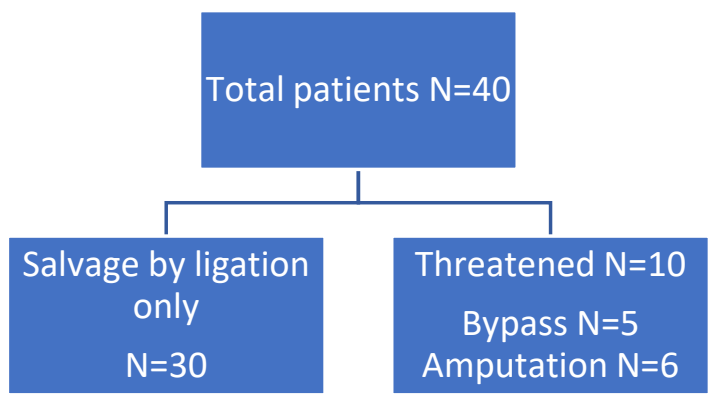

Threatened limbs (amputation group):Above knee amputation was done in 6 cases due to presence of threatened limb and bad general condition or unsafe planes for bypass construction. CIA was ligated in 3 cases, one patient presented with groin swelling, signs of sepsis and massive bleeding per rectum and after exploration, an infective fistula between iliac vessels and intestine found that required ligation of CIA to control bleeding. The other 2 cases with ligated CIA was presented with severe infection up to CIA level that it was not safe to ligate at lower level.
Another case presented with threatened limb 30 days post ligation of EIA, extraanatomical lateral ilio femoral bypass constructed but unfortunately 3 months postoperative, patient presented with sepsis and graft was removed and patient required above knee amputation due to non reconstructable critical ischemia.

Another case presented with massive bleeding and iliac vessels were ligated to control bleeding and patient required inotropic support at ICU and persistent acidosis and increased levels of CK total that required above knee amputation. 
Last case was presented by lost limb at follow up that required Above knee amputation.

Threatened Limbs (bypass group): Bypass was constructed in 5 patients with threatened limbs and good general condition and safe planes for bypass construction.

It was constructed in lateral subcutaneous tract in 4 cases and trans obturator in 1 case. All were constructed by $8 \mathrm{~mm}$ ringed graft between external iliac artery and distal part of SFA.

One case required immediate construction of bypass as he was presented with acutely ischemic but viable limb and exploration showed infected thrombosed pseudoaneurysm and construction of lateral subcutaneous ilio femoral bypass was done with success but unfortunately patient presented with pus discharge from bypass tract and loss of previous post-bypass pulse, exploration showed infected thrombosed graft that was removed and patient did not require further intervention.

Another case required bypass POD 1 and due to good medial planes, decision to create a trans-obturator bypass taken and was successfully done. primary patency was 6 months and thrombectomy required as case presented with acute ischemia symptoms.

Another 2 cases required bypass POD 2 in lateral subcutaneous planes, loss of postbypass pulses occurred in 6 months but no further intervention required, as they were presented with non-limiting claudication pain.

In last case, bypass was constructed POD 30 as patient was presented with critical ischemia. Extraanatomical lateral ilio femoral bypass constructed but unfortunately 3 months post-operative, patient presented with sepsis and graft was removed and patient required above knee amputation.
There has been no report to investigate which characteristic infected femoral artery pseudoaneurysm can be treated by artery ligation and local debridement alone without any fear of ischemic complications. ${ }^{(3)}$

Qui et al tried to correlate between addiction history and outcome and he stated that IV addiction for more than 5 years have a favorable outcome. They mentioned the IV addiction duration in general regardless mentioning duration of groin use.

The other study done on this topic done by El-Ahwal et al. ${ }^{(4)}$ as they studied the mode of presentation, site of ligation, pedal Doppler flow post ligation and Pre and postoperative ABI, they concluded that level of ligation and Doppler flow post ligation were predictors of limb outcome but their study unfortunately was small numbered, short term follow up and with loss of follow up of patients.

The determinants we chose are determinates that we thought may directly or indirectly affect limb viability post arterial ligation and they are mainly discussing the factors that may affect collateral circulation around hip joint and thus limb viability and outcome, those determinants are combined from the previous studies with additions: Preoperative ABI, Level of ligation, duration of intravenous drug abuse, Extent of infection (above or below inguinal ligament), Presence or absence of DVT, duration of symptoms and duration of affected groin use.

In contrary to Qui et al, we found that duration of affected groin use in years instead of whole duration of IV addiction was statistically significant for limb salvage as well as duration of symptoms (table 8). This could be explained by time needed for collaterals development.

Pre and immediate post-operative $\mathrm{ABI}$ and percent of reduction between both found to be statistically significant for limb salvage (table $11)$. 
Level of ligations statistically significant (table 12) As all patients with ligated CIA required limb amputation and patients with ligated iliac vessels developed more percent of reduction in ABI post operatively than patients with ligated femoral vessels only and our results are supported by El-Ahwal et al. ${ }^{(4)}$ and Arora et al. ${ }^{(8)}$ and this may be explained by preservation of collateral vessels as deep circumflex iliac and inferior epigastric vessels. We also think that ostial ligation of affected vessels is better than deep ligation that may affect collaterals and hence limb viability and outcome.

Our results go with El Ahwal et al ${ }^{(4)}$ as regard presenting symptom, we found that patients presented with hemorrhage had unfavorable outcome (table 9).

Presence or absence of DVT and infection level were not statistically significant for limb salvage. 6 patients lost along follow up time.

We suggest a simple algorithm pattern for management IFAP patients:

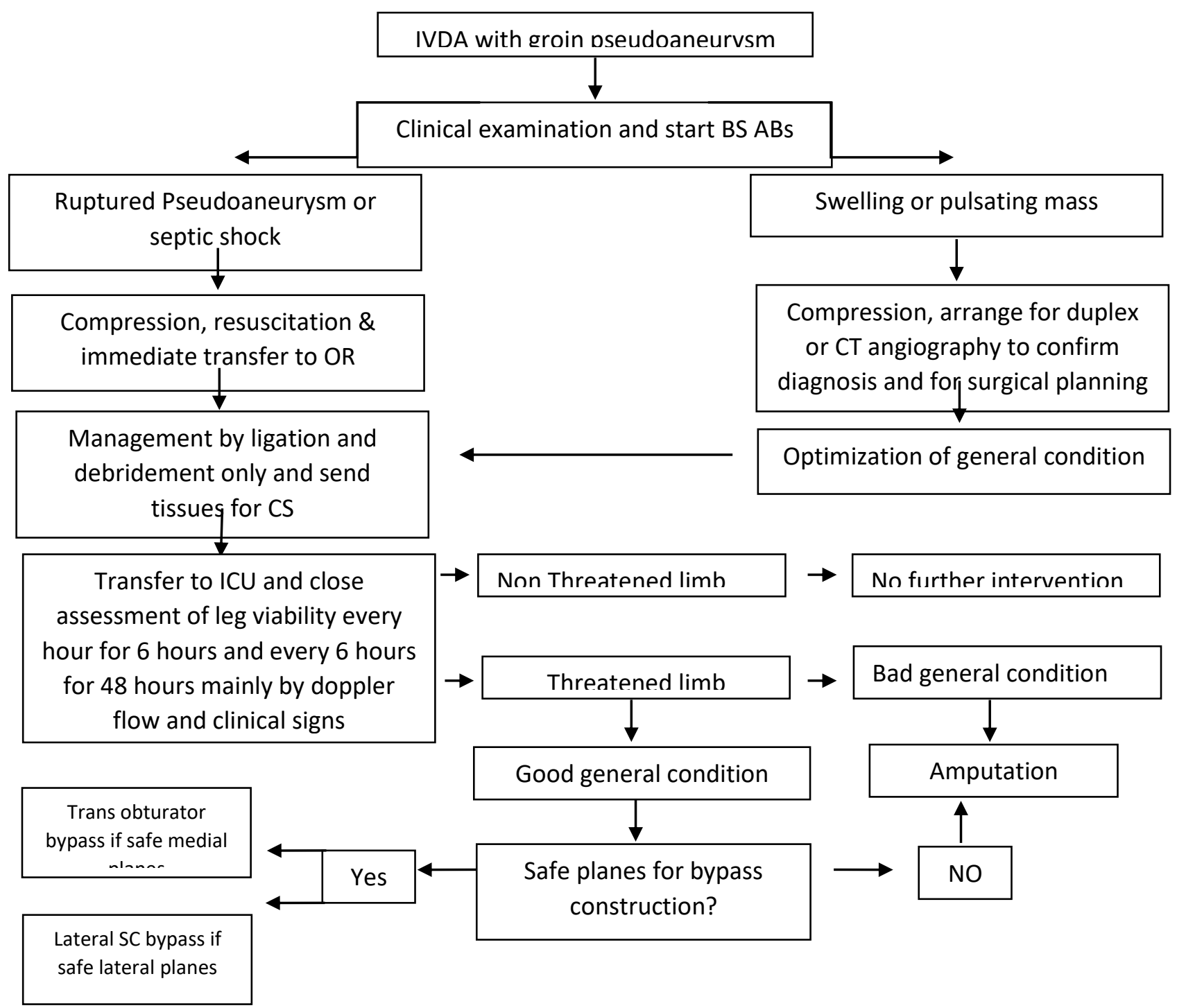

Diagram (1): Pseudoaneurysm management algorithm. 


\section{Conflict of interests:}

The authors declare that there is no conflict of interests regarding the publication of this paper.

\section{REFERENCES:}

1. Rammell J, Kansal N, Bhattacharya V. Ligation Without Revascularisation is Safe and Effective in the Management of Infected Femoral Artery Pseudoaneurysms Secondary to Intravenous Drug Abuse. International Journal of Surgery. 2017;47:S105.

2. Stevenson RP, Tolias C, Hussey K, Kingsmore DB. $\quad<\mathrm{p}>$ Mycotic pseudoaneurysm in intravenous drug users: current insights $</ p\rangle$. Research Reports in Clinical Cardiology. 2019; Volume 10:1-6.

3. Qiu J, Zhou W, Zhou W, Tang X, Yuan Q, Zhu X, et al. The Treatment of Infected Femoral Artery Pseudoaneurysms Secondary to Drug Abuse: 11 Years of Experience at a Single Institution. Annals of Vascular Surgery. 2016;36:35-43.

4. Elahwal M, Gaweesh AS, Elemam A, Moustafa SJAovs. Predictors of Limb Outcome Following Arterial Ligation of Infected Femoral Pseudoaneurysms in Drug Abusers. 2020;65:130-6.

5. DeBakey ME, Simeone FAJAos. Battle injuries of the arteries in World War II: an analysis of 2,471 cases. 1946;123(4):534.

6. Mousavi S, Saberi A, Tadayon N, Zeynalzadeh M, Kavyani AJACB. Femoral artery ligation as treatment for infected pseudo-aneurysms, secondary to drug injection. 2010;110(2):200-2.

7. Georgiadis GS, Lazarides MK, Polychronidis A, Simopoulos CJAjos. Surgical treatment of femoral artery infected false aneurysms in drug abusers. 2005;75(11):1005-10.
8. Arora S, Weber MA, Fox CJ, Neville R, Lidor A, Sidawy AN. Common femoral artery ligation and local debridement: A safe treatment for infected femoral artery pseudoaneurysms. Journal of Vascular Surgery. 2001;33(5):990-3.

9. Naqi SA, Khan HM, Akhtar S, Shah TA. Femoral Pseudoaneurysm in Drug Addicts Excision without Revascularization is a Viable Option. European Journal of Vascular and Endovascular Surgery. 2006;31(6):585-7.

10. Klonaris C, Katsargyris A, Papapetrou A, Vourliotakis G, Tsiodras S, Georgopoulos $S$, et al. Infected femoral artery pseudoaneurysm in drug addicts: The beneficial use of the internal iliac artery for arterial reconstruction. Journal of Vascular Surgery. 2007;45(3):498-504.

11. Lashkarizadeh MR, Ashrafganguie M, Ashrafganguie MJJcpSP. Surgical management of femoral artery pseudoaneurysms secondary to drug abuse. 2011;21(11):672-5.

12. Majeed M, Farooq U, Zia N, Hanif M, Khan MJJ. Infected femoral pseudoaneurysms 'the optimum management'. 2008;12:72-4.

13. Pradhan S, Shrestha KJJoGP, Nepal EMo. Management of Femoral pseudoaneurysms in intravenous drugs users-A bubble trouble. 2011;2(3):22-5.

14. Tan K-K, Chen K, Chia K-H, Lee C-W, Nalachandran SJWjos. Surgical management of infected pseudoaneurysms in intravenous drug abusers: single institution experience and a proposed algorithm. 2009;33(9):1830-5.

15. Antoniou, George A., et al. "Endovascular stent-graft repair of bleeding common femoral artery pseudoaneurysm in intravenous drug users: a bridge to surgical reconstruction." Vasa 43.6 (2014): 473-476. 
نسبة ومحددات انقاذ الاطراف السفلية بعد ربط الثرايين المصابة بالتمدد الثرياني الكاذب الملتهب في مرضى الحقن الخاطئ

د. عبد الرحمن مجديأحمد , أد. مصطفى سليمان عبد الباري , أم د. عمرو نبيل كامل

الملخص العربي

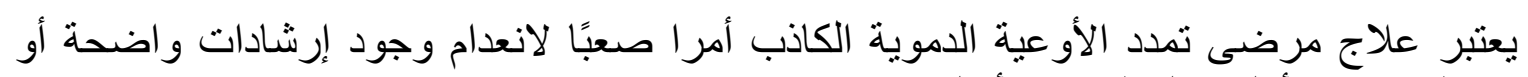

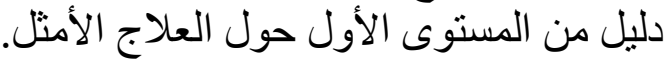
يعتبر الربط مع إعادة التروية الانتقائية خيار علاج معقول. حيث أن استراتيجية الربط التئ الشرياني

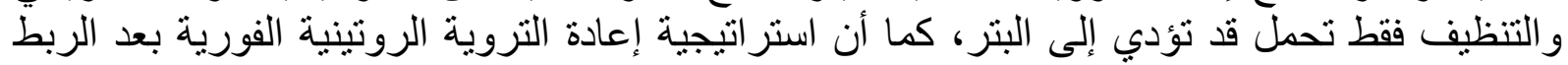

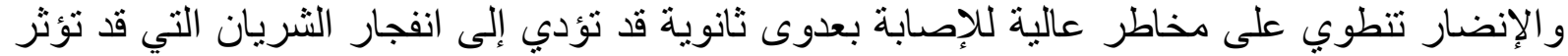

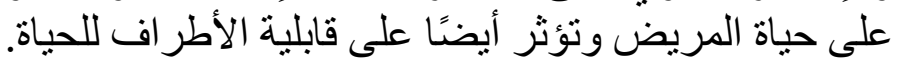

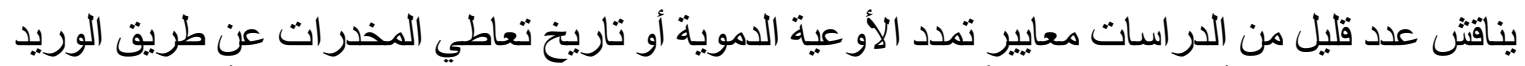

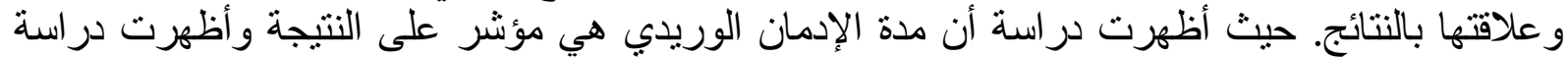

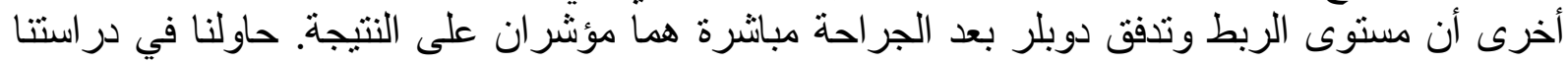

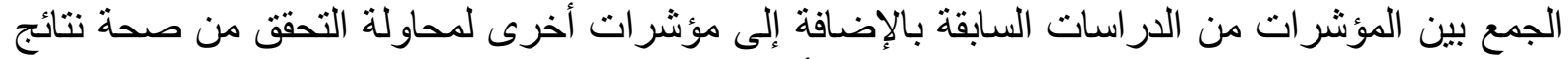
الار اسات السابقة والكثف عن المؤشر ات التش المحتملة الأخرى للنتائج.

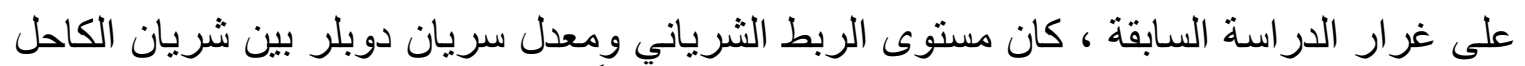

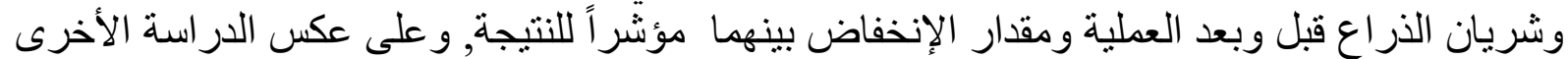

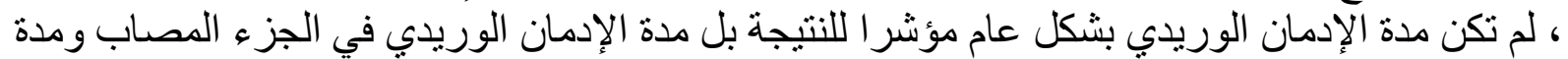
وطبيعة العرض الظاهر من المريض كلها مؤشر ات للنتيجة.

تعتبر الدورة الدموية الجانبية حول مفصل الورك أمرًا بالغ الأهمية و العو امل التي تحافظة على الدئل الدورة

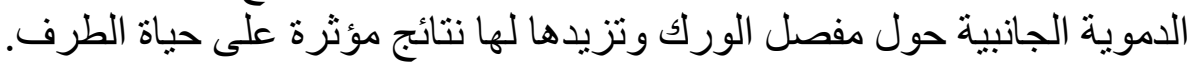

